\title{
CSR and Corporate Financial Performance: An Inter-Sectorial Analysis
}

\author{
Antonio Salvi ${ }^{1}$, Emanuele Doronzo ${ }^{1}$, Anastasia Giakoumelou ${ }^{1} \&$ Felice Petruzzella ${ }^{1}$ \\ ${ }^{1}$ Department of Economics and Management, LUM Jean Monnet University, Bari, Italy \\ Correspondence: Felice Petruzzella, Department of Economics and Management, LUM Jean Monnet University, \\ Bari, Italy. E-mail: petruzzella@lum.it
}

Received: August 3, 2019

doi:10.5539/ijbm.v14n11p193
Accepted: September 20, 2019

Online Published: October 19, 2019

URL: https://doi.org/10.5539/ijbm.v14n11p193

\begin{abstract}
This study examines the relationship between corporate social responsibility (CSR) and corporate financial performance (CFP), shedding new light on the lack of academic consensus and prevailing failure to deal with endogeneity in data. To this purpose, the authors recalculate ESG performance starting from the four pillars (economic, environmental, governance and social) provided by Thomson Reuters' Asset4 database, able to determine a firm's CSP. We adjust each ESG pillar score accounting for the firm's sector, size and headquarter geographic area. We empirically test the relationship with a Generalized Method of Moments approach (GMM) in order to tackle the widely disputed endogeneity issues arising in this type of datasets.
\end{abstract}

Results highlight a positive relationship between CSR, as measured in a tailored manner in this study, and corporate financial performance.

Keywords: CSR, financial performance, GMM, endogeneity

\section{Introduction}

The relationship between corporate social responsibility (CSR) and corporate financial performance (CFP) has gained a growing importance over the past decades. The corporate world presents an upward trend of investing in a triple bottom-line performance that moves past mere profitability into effective relationship management with the firm's various stakeholders (Gangi et al., 2018). The reasons appear to go further than mere ethical considerations. As a matter of fact, the most forward-looking companies have seized the opportunities offered by the implementation of corporate sustainable strategies and are those that have best managed the negative impacts during recession phases (Ellis \& Bastin, 2011; Salvi et al., 2018).

Scholars have examined the antecedents of CSR activities in order to explain their impact on firm outcomes, especially in terms of profitability, innovation, productivity and market appreciation (Gangi et al., 2018). The neoclassical economic theory states that the implementation of sustainable practices could decrease firm profitability due to increased associated costs (Manrique, 2017). Friedman (1970) views CSR activities that exceed legally binding minimum standards as expensive additional costs for shareholders that should be reduced in order to improve the economic performance. However, the majority of researchers support the existence of a positive and significant relationship between CSR and CFP (King \& Lenox, 2001; McWilliams \& Siegel, 2001; Campbell, 2007; Dyduch \& Krasodomska, 2017). Moreover, consistent with the "Stakeholder theory" (Freeman, 1984) and the "Natural resource-based view" (Barney, 1991; Bansal, 2005) Fatemi et al. (2017) come across findings that support a strong positive relationship between social responsibility and firm value. Despite the latter, scholars meet with a lack of consensus on the impact of CSR on CFP (Clark \& Viehs, 2014; Endrikat, 2016; Fatemi et al., 2017). Even though a long stream of researchers supports the existence of a relationship between CSR and CFP (Margolis et al., 2007), there is a school of thought suggesting this relationship is positive but not relevant or even inconclusive and mostly negative (Horvathova, 2010; Lioui \& Sharma, 2012). The reasons behind such controversial results are multiple: (1) differences in the operationalization of CSR, often influenced by the sector in which the firm operates and its size (Wood \& Jones, 1995; Blasi et al., 2018); (2) differences in the operationalization of corporate economic and financial performance; (3) endogeneity issues in the data analysed, attributed to the reverse causality and omitted variables biases and able to generate inconsistent and distorted coefficients (El Ghoul et al., 2011; Attig et al., 2013; Endrikat, 2016). 
This work aims to fill the aforementioned gap by defining and tailoring a new measure for sustainability able to capture the implementation effectiveness of sustainable practices, accounting for sector peculiarities, firm size and country specific characteristics linked to CSR engagement on a corporate level and, on a second note, mitigating endogeneity risks by employing a Generalized Method of Moments (GMM) approach (Arellano \& Bover, 1995; El Ghoul et al., 2011). Researchers supporting the existence of a positive relationship between the implementation of sustainable policies and corporate financial performance assume that such practices are the result of a comprehensive strategic choice and, as a result, the firm's sector and size are of critical impact on a firm's CSR engagement (Blasi et al., 2018).

The aim of this work is to contribute to empirical literature in the field of CSR and CFP both in terms of operationalization choices and methodological approach, applying a tailor-made measure for sustainability designed to capture sector, firm and country specificities. The rest of this paper is structured as follow: in the section 2 we provide systematic literature review about the relationship between CSR and CFP; section 3 provides the specification concerning the applied methodology and the database description, section 4 explains the obtained results and in the section 5 is presented a summary and concluding remarks.

\section{Literatures Review}

The relationship between CSR and CFP remains an open debate among academics, managers and practitioners. CSR may be defined as the righteous attitude of a company towards all its stakeholders, both internal and external and towards the environment in which it operates. If positively engaged, all stakeholders may experience benefits for the company. Extensive scientific research has been carried out in order to explore whether socially responsible initiatives benefit firms in economic and financial terms, i.e. generating competitive advantage (Wagner, 2005; Soana, 2011).

Several academics imply that the implementation of sustainable strategies could decrease firms' profitability due to the high associated costs involved in production and sustainable innovation (Friedman, 1970; Manrique, 2017). More specifically, Preston and O'Bannon (1997), highlight a "negative synergy resulting in a vicious circle" through the trade-off hypothesis. According to the latter, a greater involvement in CSR leads to a deterioration of economic and financial performance with respect to competitors. Indeed, CSR engagement entails higher costs for firms, such as special machinery and equipment, facilities, materials, higher wages and benefits for employees and lastly a major number of workers to implement social performance policies (McWilliams \& Siegel, 2001). As a result, and as costs are driven higher, profits fall at the expense of shareholders' financial interests (Waddock \& Graves, 1997). Finally, the aforementioned studies support the so-called managerial opportunism hypothesis; according to Preston and O'Bannon (1997) managers try to make profits in the short term by reducing their commitment to socially responsible behavior, attempting to justify their decisions through their commitment to expensive social programs.

Nonetheless, among theories that indicate the benefits of firms moving beyond profit maximization purposes the most relevant is the "Stakeholder theory" (Freeman, 1984). According to the "Stakeholder theory" companies should incorporate sustainability, in their modus operandi, given that it fosters the production costs saving, reducing at the same time the environmental risks (McWilliams \& Siegel, 2001; Campbell, 2007; Dyduch, 2017). Within the "Stakeholder theory" framework, firms engaging in CSR practices develop a heightened skill of meeting multiple stakeholder interests and amplify their range of growth opportunities while viewed as less risky. Consequently, the relationships with all stakeholders should be catered to and fostered in order to achieve competitiveness and improved performance in the long run. Esteban-Sanchez et al. (2017) state that stronger CSR commitment can contribute to improve the firm's value; in fact, CFP will be boosted by means of a socially responsible attitude. Preston and O'Bannon (1997), Waddock and Graves (1997) and Orlitzky et al. (2003) further argue that CSP and CFP are positively associated, but it still remains to be verified whether it is indeed CSR improvements that drive higher financial benefits or the other way around, consistent with the assumption of the "Slack resources hypothesis", which claims that better financial results influence the availability of slack resources that help companies to invest in social performance activities (Waddock \& Graves, 1997; Nelling \& Webb, 2009).

The various theoretical frameworks considered so far cannot fully clarify the mechanisms that link competitive advantage and the implementation of socio-environmental strategies. This lack of causal nexus stimulated vast empirical literature focused on this relationship. The main aim of empirical literature in the field is to identify the causal link between CFP and CSP. More precisely, as pointed out by Hart and Ahuja (1996), King and Lenox (2001), El Ghoul et al. (2011) and Attig et al. (2013), the aforesaid relationship is affected by endogeneity deriving from the possibility that crucial variables have been omitted in the specification of the theoretical model 
(Vastola et al., 2017) or from reverse causality (Endrikat, 2016). It is crucial to define whether it is the richer firms that are able to use more resources in sustainable projects or more sustainable firms that obtained competitive advantage able to generate higher economic and financial performance (El Ghoul et al., 2011). As a matter of fact, according to Jo and Harjoto (2011) suggest that failure to factor endogeneity in leads to substantial error in the valuation of CSR benefits.

Taking on these gaps in existing literature, the study of the relationship between CSR and CFP has generated widely controversial results. Margolis and Walsh (2003), Orlitzky et al. (2003), Lin et al. (2009), Rettab et al. (2009) and Fatemi et al. (2015) indicate how firms with more robust CSR strategies enjoy improved economic and financial performance. Moreover, Chen and Wang (2011), Alafi and Hasoneh (2012) and Galbreath and Shum (2012) perform a statistical evaluation of the positive impact that CSR has on a firm's stakeholders. On the contrary, another stream of scholars comes across a non-significant (Alexander \& Buchholz, 1978; Renneboog et al., 2008) or negative relationship between CSR and CFP (Vance, 1975; Brammer et al., 2006), highlighting that the market does not reward efforts invested in sustainable activities. Lioui and Sharma (2012) considered two different channels through which CSR implementation has an impact on the firm's financial performance: the first channel, named "concern", indicates the direct and positive impact that the implementation of sustainable practices has on economic performance through the higher investments in research and development, while the second channel, named "strength", indicates the direct and negative impact the CSR implementation costs have on economic performance. The negative but statistically relevant relationship between Return on Assets (ROA) and Tobin's Q and CSR identified by the authors' shows that the indirect effect prevails over the direct one. According to Aupperle et al. (1985) and McGuire et al. (1988) the relationship between CSR and CFP remains an open question, since empirical results are persistently ambiguous.

A further source of ambiguity originates in the lack of a homogenous definition of corporate social performance (CSP) and CFP measures, as underlined by Wang et al. (2016). More in detail, CSR measures are multiple and diverse. The authors stress in their meta-analysis that there are many measures for CSR implementation and different approaches determine a different constitution of CSR performance. Furthermore, as put by Aupperle et al. (1985), Wood and Jones (1995) and Endrikat (2016), the main problem linked to the construction of a score able to measure the degree of a firm's CSR commitment is given by the multidimensional character of CSR practices. What is more, scholars do not present a univocal opinion also regarding the operationalization of economic and financial performance. McGuire et al. (1988), observed that each individual type of economic indicators is not free from bias. In particular, accounting-based measures only consider a firm's historical data of performance and are, thus, subject to bias of managerial control of data and accounting procedures (Briloff, 1981). On the other hand, market-based measures are determined on the prospective future earnings of a company rather than the past performance and, thus, do not provide a fair evaluation of investors when market distortion cases come up.

Furthermore, the aforementioned approaches analyse CSR practices without taking into consideration firm specificities, notwithstanding the fact that CSR is defined as an ample group of practices within the corporate agenda targeting improved stakeholder management (Barnett, 2007). The heterogeneity of the sector in which a firm operates in, for instance, is crucial in order to define the nature of a company, its average size, the types and characteristics of products it deals with and the organizational framework (Blasi et al., 2018). Griffin and Mahon (1997) argue that a multi-sector analysis can be biased in its calculation of CSP, provided that such measures are influenced by sector specificities. As highlighted by Wood and Jones (1995), it is important to consider the power that different stakeholders have to influence managerial choices within a given sector (in the Oil \& Gas industry stakeholders will be very sensitive to policies aimed at mitigating environmental risks, while in the financial sector they will be more sensitive to the implementation of social policies in support of the community). In the light of such considerations, many scholars decided to carry out empirical analyses on specific sectors (Soana, 2011). Blasi et al. (2018) conducted an inter-sectorial analysis that considers sector specificities, in terms of both financial and accounting measures. In their analysis, they provide evidence of a non-linear relationship between CSR and CFP over time: CSR may require higher costs to be implemented but it also brings benefits for firms. Results are consistent with the findings obtained by Yang (2016), suggesting that the relationship between CSR and CFP is positive in the long-run perspective and negative in the short term.

Finally, as underlined by Salvi et al. (2018), more sustainable firms reduce information asymmetries, giving investors the chance of more informed investment decisions, especially in the light of the growing attention CSR is gaining worldwide. Moreover, more sustainable firms, characterized by a superior non-financial disclosure, help investors better understand a firm's ESG strengths and weaknesses (Fatemi et al., 2017), further reducing information asymmetries. Consequently, according to the "Insurance-link effect theory" sustainable firms are 
perceived as less risky by the market due to their capacity to create a form of goodwill. This sort of goodwill mitigates the severity of negative investor reactions in case of negative future events, reducing the perceived risk and preserving firm value for shareholders (Godfrey et al., 2009).

Table 1 presents an overview of the main empirical works that deal with the relationship between CSR and CFP. The analysis of the literature generates two fundamental implications: (i) the need to appropriately measure CSP that accounts for the aforementioned specificities, and (ii) the need to adopt more robust econometric methods of analysis.

Table 1. Empirical literature on the relationship between CSR and CFP

\begin{tabular}{|c|c|c|c|c|}
\hline Authors & Dataset & CSP measures & CFP measures & Findings \\
\hline $\begin{array}{l}\text { Bragdon and } \\
\text { Marlin (1972) }\end{array}$ & $\begin{array}{l}131 \text { pulp and paper companies } \\
\text { from COMPUSTAT and CEP } \\
\text { dataset, } 1965-1970\end{array}$ & $\begin{array}{l}\text { Indices of pollution } \\
\text { records }\end{array}$ & Earnings, ROE and ROC & Positive relationship \\
\hline $\begin{array}{l}\text { Alexander and } \\
\text { Buchholz } \\
\text { (1978) }\end{array}$ & $\begin{array}{l}\text { U.S. corporation for the } \\
\text { period } 1970-1974 \text { from } \\
\text { COMPUSTAT }\end{array}$ & $\begin{array}{l}\text { Corporate social } \\
\text { responsibility surveys }\end{array}$ & Stock market performance & Not significant relationship \\
\hline $\begin{array}{l}\text { Shane and } \\
\text { Spicer (1983) }\end{array}$ & $\begin{array}{l}\text { CRSP financial tapes and CEP } \\
\text { pollution performance data }\end{array}$ & $\begin{array}{l}\text { Indices of pollution } \\
\text { records }\end{array}$ & Stock market performance & Positive relationship \\
\hline $\begin{array}{l}\text { Aupperle et } \\
\text { al. (1985) }\end{array}$ & Fortune 500 companies & $\begin{array}{l}\text { Forced choice instrument } \\
\text { administered to corporate } \\
\text { CEOs }\end{array}$ & ROA & Not significant relationship \\
\hline $\begin{array}{l}\text { Jaggi and } \\
\text { Freedman } \\
(1992)\end{array}$ & $\begin{array}{l}\text { Monthly pollution report of } \\
\text { plants from } 13 \text { firms for } 1975 \\
\text { to } 1980 \text {. Financial data from } \\
\text { COMPUSTAT }\end{array}$ & Pollution index & $\begin{array}{l}\text { Net Income, Return on } \\
\text { Equity, Return of Assets, } \\
\text { Cash Flow/Equity, Cash } \\
\text { Flow/Assets, and price } \\
\text { earnings ratio }\end{array}$ & $\begin{array}{l}\text { In the short run weak and } \\
\text { negative relationship }\end{array}$ \\
\hline $\begin{array}{l}\text { Hamilton } \\
(1995)\end{array}$ & $\begin{array}{l}\text { TRI data and CRSP data for } \\
893 \text { U.S. firms }\end{array}$ & $\begin{array}{l}\text { Media coverage of TRIs } \\
\text { before } \\
\text { the date of initial public } \\
\text { release of TRI data }\end{array}$ & Abnormal stock return & Positive relationship \\
\hline $\begin{array}{l}\text { Hart and } \\
\text { Ahuja (1996) }\end{array}$ & $\begin{array}{l}127 \text { firms from the Standard } \\
\text { and Poor's } 500\end{array}$ & $\begin{array}{l}\text { Emissions efficiency } \\
\text { index, Equal to ratio of } \\
\text { reported emissions in } \\
\text { pounds to the company's } \\
\text { revenues }\end{array}$ & ROS, ROA and ROE & Positive relationship \\
\hline $\begin{array}{l}\text { Klassen and } \\
\text { McLaughlin } \\
\text { (1996) }\end{array}$ & $\begin{array}{l}\text { The Nexis and UPI databases } \\
\text { and CRSP data }\end{array}$ & $\begin{array}{l}\text { Environmental award } \\
\text { winners and } \\
\text { environmental crises }\end{array}$ & Abnormal stock return & Positive relationship \\
\hline $\begin{array}{l}\text { Preston and } \\
\text { O'Bannon } \\
(1997)\end{array}$ & $\begin{array}{l}\text { Fortune survey and } \\
\text { COMPUSTAT dataset }\end{array}$ & $\begin{array}{l}3 \quad \text { different social } \\
\text { performance reputation } \\
\text { ratings }\end{array}$ & ROE, ROA and ROI & Positive relationship \\
\hline $\begin{array}{l}\text { Russo and } \\
\text { Fouts (1997) }\end{array}$ & $\begin{array}{l}477 \text { firms ranked by the } \\
\text { Franklin Research and } \\
\text { Development Corporation }\end{array}$ & Environmental ratings & ROA & Positive relationship \\
\hline $\begin{array}{l}\text { Waddock and } \\
\text { Graves (1997) }\end{array}$ & $\begin{array}{l}\text { S\&P } 500 \text { and Kinder, } \\
\text { Lydenberg, and Domini \& Co. } \\
\text { (KLD) }\end{array}$ & $\begin{array}{l}\text { Index of CSP based on } \\
\text { the eight corporate social } \\
\text { performance attributes }\end{array}$ & ROA, ROE and ROS & Positive relationship \\
\hline $\begin{array}{l}\text { Stanwick and } \\
\text { Stanwick } \\
(1998)\end{array}$ & $\begin{array}{l}\text { Fortune Corporate Reputation } \\
\text { Index and EPA's Toxic } \\
\text { Release Inventory Report }\end{array}$ & $\begin{array}{l}\text { Environmental } \\
\text { performance, based on } \\
\text { the level of pollution } \\
\text { emissions released by the } \\
\text { firm }\end{array}$ & Level of profitability & Positive relationship \\
\hline $\begin{array}{l}\text { Dowell et al. } \\
(2000)\end{array}$ & $\begin{array}{l}\text { U.S. Standard and Poor's } 500 \\
\text { (COMPUSTAT) and Investor } \\
\text { Responsibility Research }\end{array}$ & $\begin{array}{l}\text { Environmental and social } \\
\text { performance derived from } \\
\text { data IRRC }\end{array}$ & Tobin's Q & Positive relationship \\
\hline
\end{tabular}




\begin{tabular}{|c|c|c|c|c|}
\hline & Center's (IRRC) Corporate & & & \\
\hline & Environmental Profile & & & \\
\hline $\begin{array}{l}\text { King and } \\
\text { Lenox } \\
(2001)\end{array}$ & $\begin{array}{l}\text { U.S. EPA's Toxic Release } \\
\text { Inventory (TRI) and Standard } \\
\text { \& Poor's Compustat database }\end{array}$ & $\begin{array}{l}\text { Total, relative and } \\
\text { industry emissions }\end{array}$ & $\begin{array}{l}\text { Tobin's Q, ROE, ROA and } \\
\text { ROI }\end{array}$ & Positive relationship \\
\hline $\begin{array}{l}\text { Al-Tuwaijri et } \\
\text { al., (2004) }\end{array}$ & $\begin{array}{l}\text { IRRC database and cross- } \\
\text { sectional sample of } 198 \text { US } \\
\text { Standard \& Poor } 500\end{array}$ & $\begin{array}{l}\text { The ratio of toxic waste } \\
\text { recycled to total toxic } \\
\text { waste generated }\end{array}$ & $\begin{array}{l}\text { Industry-adjusted annual } \\
\text { return }\end{array}$ & Positive relationship \\
\hline $\begin{array}{l}\text { Lorraine et al. } \\
(2004)\end{array}$ & $\begin{array}{l}\text { Spotlight on Environmental } \\
\text { Performance report and } \\
\text { DATASTREAM }\end{array}$ & Good news and bad news & Abnormal return & Not significant relationship \\
\hline $\begin{array}{l}\text { Hassel et al. } \\
(2005)\end{array}$ & $\begin{array}{ll}\text { Trust database of } \\
\text { Bonnier-Findata, Sweden }\end{array}$ & $\begin{array}{l}\text { Index of environmental } \\
\text { performance }\end{array}$ & Stock market performance & Positive relationship \\
\hline $\begin{array}{l}\text { Wagner } \\
(2005)\end{array}$ & $\begin{array}{l}37 \text { paper firms in four EU } \\
\text { countries over the period from } \\
1995 \text { to } 1997\end{array}$ & $\begin{array}{l}\text { Emission of toxic } \\
\text { chemicals and total } \\
\text { energy and water input } \\
\text { per output }\end{array}$ & ROCE, ROE and ROS & $\begin{array}{l}\text { Controversial results; } \\
\text { U-shaped relationship }\end{array}$ \\
\hline $\begin{array}{l}\text { Brammer et } \\
\text { al. (2006) }\end{array}$ & $\begin{array}{l}\text { Ethical Investment Research } \\
\text { Service and Datastream. }\end{array}$ & $\begin{array}{l}\text { Community performance, } \\
\text { environmental } \\
\text { performance and } \\
\text { employee performance: } 6 \\
\text { categories }\end{array}$ & Stock market return & Negative relationship \\
\hline $\begin{array}{l}\text { Nelling and } \\
\text { Webb (2009) }\end{array}$ & $\begin{array}{lrr}600 \quad \text { U.S. } & \text { firms } & \text { from } \\
\text { COMPUSTAT } & \text { and } & \text { KLD } \\
\text { database } & & \end{array}$ & $\begin{array}{l}\text { CSR rating calculated as } \\
\text { weighted by the authors }\end{array}$ & $\begin{array}{l}\text { ROA and market-based } \\
\text { measure }\end{array}$ & Ambiguous results \\
\hline $\begin{array}{l}\text { Lioui and } \\
\text { Sharma } \\
(2012)\end{array}$ & KLD STATS Inc. & $\begin{array}{l}\text { Environmental Strength } \\
\text { and environmental } \\
\text { Concern (measures built } \\
\text { by the authors) }\end{array}$ & ROA and Tobin's Q & Negative relationship \\
\hline $\begin{array}{l}\text { Attig et al. } \\
(2013)\end{array}$ & $\begin{array}{l}1,585 \text { US firms over the } \\
\text { period } 1991-2010 \text { was drawn } \\
\text { by different data providers }\end{array}$ & $\begin{array}{l}\text { CSR score built by the } \\
\text { authors }\end{array}$ & Credit rating & Positive relationship \\
\hline Yang (2016) & $\begin{array}{l}399 \text { firms over a period from } \\
2001 \text { to } 2008 \text { using } \\
\text { Compustat and the KLD } \\
\text { Domini } 400 \text { Social Index }\end{array}$ & $\begin{array}{l}\text { Degree of CSR } \\
\text { engagement in short term } \\
\text { and long term }\end{array}$ & Market to book ratio & $\begin{array}{l}\text { Negative relationship in the } \\
\text { short run and positive } \\
\text { relationship in the long run }\end{array}$ \\
\hline $\begin{array}{l}\text { Blasi et al. } \\
(2018)\end{array}$ & $\begin{array}{l}\text { MSCI ESG KLD STATS } \\
\text { Dataset and DATASTREAM } \\
(988 \text { US companies from } \\
2003 \text { to } 2015)\end{array}$ & $\begin{array}{l}\text { Normalized measure for } \\
\text { CSR performance }\end{array}$ & $\begin{array}{l}\text { The stock market- based } \\
\text { and accounting-based } \\
\text { economic measures }\end{array}$ & $\begin{array}{lr}\text { Positive relationship } \\
\text { between market-based } \\
\text { performance r and } \\
\text { social-environmental }\end{array}$ \\
\hline $\begin{array}{l}\text { Cui et al. } \\
(2018)\end{array}$ & $\begin{array}{l}\text { MSCI ESG KLD STATS } \\
\text { Dataset and COMPUSTAT of } \\
830 \text { US companies from } 1991 \\
\text { to } 2010\end{array}$ & $\begin{array}{l}\text { Normalized measure for } \\
\text { CSR performance }\end{array}$ & Stock market return & Positive relationship \\
\hline $\begin{array}{l}\text { Fijakowska } \\
\text { et al. (2018) }\end{array}$ & $\begin{array}{l}\text { The } 20 \text { biggest public banks } \\
\text { in CEEC in the period } \\
2012-2016 \\
\text { CSR/sustainable report and } \\
\text { EMIS database }\end{array}$ & $\mathrm{CSR} /$ sustainable report & $\mathrm{ROE}$ and ROA & Ambiguous results \\
\hline
\end{tabular}

Based on what has been thus far discussed, we posit the following research hypotheses:

H1a: There is a positive relationship between a firm's economic performance and its accounting performance (ROA), ceteris paribus;

H1b: There is a positive relationship between a firm's environmental performance and its accounting performance (ROA), ceteris paribus; 
H1c: There is a positive relationship between a firm's governance performance and its accounting performance (ROA), ceteris paribus;

H1d: There is a positive relationship between a firm's social performance and its accounting performance (ROA), ceteris paribus;

H2a: There is a positive relationship between a firm's economic performance and its financial performance (Tobin's Q), ceteris paribus;

$\mathrm{H} 2 \mathrm{~b}$ : There is a positive relationship between a firm's environmental performance and its financial performance (Tobin's Q), ceteris paribus;

$\mathrm{H} 2 \mathrm{c}$ : There is a positive relationship between a firm's governance performance and its financial performance (Tobin's Q), ceteris paribus;

H2d: There is a positive relationship between a firm's social performance and its financial performance (Tobin's Q), ceteris paribus.

\section{Methodology}

\subsection{Data Collection and Variables}

We draw our data from the S\&P Global 1200 (Note 1) index for the period 2011-2017. This index consists of 1,223 companies operating in ten sectors worldwide: Basic Materials, Consumer Goods, Consumer Services, Financials, Health Care, Industrials, Oil \& Gas, Technology, Telecommunications and Utilities). Our final sample comprises 8,561 firms' observations.

We use the Thomson Reuters' Asset4 database to draw ESG data that measure corporate performance in four fields: economic, environmental, social, and corporate governance (Ioannou \& Serafeim, 2015; Chollet \& Sandwidi, 2018). Following research in the field of examination, ESG data provided by the Asset 4 database are reliable proxies to describe a firm's CSR engagement (Semenova \& Hassen, 2014). Moving further, we extract financial data from Thomson Reuters' Datastream. Finally, we employ the Worldwide Governance Indicators (Note 2) (WGI) to obtain country legal, institutional and political data (Kaufmann et al., 2009). Tables 2 and 3 summarize the main descriptive statistics for our sample, by geographical area and industry sector.

Table 2. Sample composition by industry

\begin{tabular}{llll}
\hline Sector & Number & Frequency & Cumulative distribution \\
\hline Financials & 260 & $21.26 \%$ & $21.26 \%$ \\
Industrials & 217 & $17.74 \%$ & $39.00 \%$ \\
Consumer Goods & 163 & $13.33 \%$ & $52.33 \%$ \\
Consumer Services & 147 & $12.02 \%$ & $64.35 \%$ \\
Health Care & 95 & $7.77 \%$ & $72.12 \%$ \\
Basic Materials & 90 & $7.36 \%$ & $79.48 \%$ \\
Technology & 85 & $6.95 \%$ & $86.43 \%$ \\
Oil \& Gas & 68 & $5.56 \%$ & $91.99 \%$ \\
Utilities & 67 & $5.48 \%$ & $97.47 \%$ \\
Telecommunications & 31 & $2.53 \%$ & $100.00 \%$ \\
Total & 1,223 & $100.00 \%$ & $100.00 \%$ \\
\hline
\end{tabular}

Table 3. Sample composition by geographical area

\begin{tabular}{llll}
\hline Geographical area & Number & Frequency & Cumulative distribution \\
\hline North America & 546 & $44.64 \%$ & $44.64 \%$ \\
Europe & 382 & $31.23 \%$ & $75.87 \%$ \\
Asia & 200 & $16.35 \%$ & $92.22 \%$ \\
South America and Oceania & 95 & $7.78 \%$ & $100.00 \%$ \\
Total & 1,223 & $100.00 \%$ & $100.00 \%$ \\
\hline
\end{tabular}

\subsection{Dependent Variables}

We measure profitability and firm value using Return on Assets (ROA) and Tobin's Q as the respective proxies. In particular, ROA is calculated dividing the firm's net income by its total assets and measures how efficiently 
firm assets are employed to generate financial profit (Cho et al., 2019). Tobin's Q, instead, is calculated dividing the firm's market value of total assets by their cost of replacement.

\subsection{Independent Variables}

Empirical literature in the field of interest has demonstrated that one of the reasons behind the poor reliability of results obtained by researchers during the past decades is the non-univocal definition of a variable able to measure CSR commitment (Endrikat, 2016). To this purpose, Hart and Ahuja (1996) considered the degree of toxic emissions produced by the company as a reliable measure for the firm's CSR commitment. Opposite Waddock and Graves (1997) suggest a multidimensional nature of CSP, using a complex operationalization process to define their measure of firm sustainability. Following the most relevant literature in the field, we take on the four pillars determining the sustainable score provided by Asset4 (economic, environmental, social and governance), in order to re-elaborate a score able to account for sector specificities, company size and headquarter geographic area (Waddock \& Graves, 1997; Attig et al., 2013; Blasi et al., 2018).

The first step in our operationalization process is the construction of the reference benchmarks based on the firm's sector (indicated by the company's industry SIC code). Subsequently, for each sector we measure relative size, considering also the headquarter geographic area (Note 3). For each sector and geographic area we also calculate the distribution of firm size (calculated as the natural logarithm of total assets), after generating a dummy variable to identify "big" and "small" firms operating in the same sector and geographic area.

At a second stage, we compute the new pillars of CSP using the following formula:

$$
\text { Score }_{i}=\frac{\text { score } A 4_{i}-\text { average score SSC }}{\text { st.dev.score SSC }}
$$

In the formula, score ${ }_{\mathrm{i}}$ represents the score for each CSP pillar as calculated by the authors; score $\mathrm{A}_{\mathrm{i}}$ represents the original score for each CSP pillar as provided by Asset4; average score SSC represents the average CSP pillar score calculated considering the firm's sector, size and headquarter geographic area; st. dev. score SSC represents the standard deviation of each CSP pillar score calculated considering the firm's sector, size and the geographic area.

The value of the recalculated scores is rescaled in order to obtain values between 0 and 100 , where 0 is associated to firms with the weakest CSP and to firms with the strongest CSP.

\subsection{Control Variables}

A set of control variables has been introduced in the econometric analysis following prevailing literature in the field (Hart \& Ahuja, 1996; King \& Lenox, 2001; Chollet \& Sandwidi, 2018; Salvi et al., 2018). Control variables employed are classified into two categories: (1) firm characteristics (firm size, EBITDA margin and financial leverage) and (2) country characteristics (regulatory quality, rule of law index and control of corruption). Table 4 presented a summary of variables employed in the analysis.

Table 4. Variables summary

\begin{tabular}{|c|c|c|c|}
\hline Variable & Symbol & Definition & Source \\
\hline \multicolumn{4}{|c|}{ DEPENDENT VARIABLES } \\
\hline $\begin{array}{l}\text { Return } \\
\text { Assets }\end{array}$ & ROA & The Return on Assets is calculated as net income to total asset (measured as percentage) & Datastream \\
\hline Tobin's Q & TQ & $\begin{array}{l}\text { The Tobin's Q is calculated as annual market value divided by replacement value of the } \\
\text { firm' asset replacement }\end{array}$ & Datastream \\
\hline \multicolumn{4}{|c|}{ INDEPENDENT VARIABLES } \\
\hline Economic & $\mathrm{ECO}$ & $\begin{array}{l}\text { The economic pillar measures a company's capacity to improve its profits by increasing } \\
\text { production process innovations or by enforcing a loyal and productive employee and } \\
\text { supplier base }\end{array}$ & Asset 4 \\
\hline Environmental & ENV & $\begin{array}{l}\text { The environmental pillar measures a company's impact on ecosystem. The it shows } \\
\text { how a firm implements management activities to reduce environmental risks and take } \\
\text { environmental opportunities to produce long-term shareholder value }\end{array}$ & Asset4 \\
\hline Social & SOC & $\begin{array}{l}\text { The social pillar measures if the management activities generate trust and loyalty with } \\
\text { its workforce, customers, and society }\end{array}$ & Asset4 \\
\hline Governance & GOV & $\begin{array}{l}\text { The corporate governance pillar measures if the board decisional systems and processes } \\
\text { guarantee the accomplish of long-term shareholder aims }\end{array}$ & Asset4 \\
\hline
\end{tabular}




\begin{tabular}{|c|c|c|c|}
\hline \multicolumn{4}{|c|}{ CONTROL VARIABLES } \\
\hline Firm size & FS & $\begin{array}{l}\text { The variable represents the firm's size and is calculated as the natural logarithm of the } \\
\text { company's total assets }\end{array}$ & Datastream \\
\hline EBITDA margin & $\mathrm{E} \%$ & $\begin{array}{l}\text { The variable represents the firm's EBITDA margin, a measure of profitability, } \\
\text { calculated by dividing the company's EBITDA by its net sales or revenues }\end{array}$ & Datastream \\
\hline $\begin{array}{l}\text { Financial } \\
\text { leverage }\end{array}$ & FL & $\begin{array}{l}\text { The variable represents the firm's leverage and is calculated as the company's total debt } \\
\text { divided by its shareholder's equity }\end{array}$ & Datastream \\
\hline $\begin{array}{l}\text { Regularity } \\
\text { quality }\end{array}$ & RQ & $\begin{array}{l}\text { The regulatory quality measures the perceptions of the ability of the government to } \\
\text { formulate and implement sound policies and regulations that permit and promote } \\
\text { private sector development }\end{array}$ & $\begin{array}{l}\text { Worldwide } \\
\text { Governance } \\
\text { Indicators }\end{array}$ \\
\hline Rule of law & RL & $\begin{array}{l}\text { The rule of law measures the perceptions of the extent to which agents have confidence } \\
\text { in and abide by the rules of society, and in particular the quality of contract } \\
\text { enforcement, property rights, the police, and the courts, as well as the likelihood of } \\
\text { crime and violence }\end{array}$ & $\begin{array}{l}\text { Worldwide } \\
\text { Governance } \\
\text { Indicators }\end{array}$ \\
\hline $\begin{array}{l}\text { Control } \\
\text { corruption }\end{array}$ & $\mathrm{CC}$ & $\begin{array}{l}\text { The control of corruption measures the perceptions of the extent to which public power } \\
\text { is exercised for private gain, including both petty and grand forms of corruption, as well } \\
\text { as "capture" of the state by elites and private interests }\end{array}$ & $\begin{array}{l}\text { Worldwide } \\
\text { Governance } \\
\text { Indicators }\end{array}$ \\
\hline
\end{tabular}

Table 5 reports descriptive statistics and the correlation matrix of the variables employed to perform the empirical analysis. The Spearman correlation matrix for the variables indicates a positive association between CSP pillars and financial performance, while all of the above correlations result statistically significant, at least at the 10 percent level. Nevertheless, correlation coefficients should be interpreted with caution because they do not control for other firm characteristics in the cross section. To further examine the multivariate effect of other control variables on the ESG pillars and CFP association, we run multivariate regressions in the following section.

Table 5. Descriptive statistics and matrix correlation

\begin{tabular}{|c|c|c|c|c|c|c|c|c|c|c|c|c|c|c|c|c|}
\hline & & N. Obs. & Mean & St. Dev. & 1 & 2 & 3 & 4 & 5 & 6 & 7 & 8 & 9 & 10 & 11 & 12 \\
\hline ROA & 1 & 8,561 & 7.345 & 8.507 & 1.00 & & & & & & & & & & & \\
\hline TQ & 2 & 8,561 & 2.368 & 3.480 & $0.88 * * *$ & 1.00 & & & & & & & & & & \\
\hline ECO & 3 & 8,561 & 62.744 & 32.515 & $0.07 * * *$ & $0.04 * * *$ & 1.00 & & & & & & & & & \\
\hline ENV & 4 & 8,561 & 61.940 & 35.021 & $0.06^{* * *}$ & $0.03 * * *$ & $0.99 * * *$ & 1.00 & & & & & & & & \\
\hline GOV & 5 & 8,561 & 56.684 & 34.255 & $0.07 * * *$ & $0.04 * * *$ & $0.98^{* * * *}$ & $0.98 * * *$ & 1.00 & & & & & & & \\
\hline SOC & 6 & 8,561 & 61.688 & 33.677 & $0.07 * * *$ & $0.04 * * *$ & $0.98 * * *$ & $0.98^{* * * *}$ & $0.97 * * *$ & 1.00 & & & & & & \\
\hline FS & 7 & 8,561 & 16.028 & 1.889 & $-0.57^{* * *}$ & $-0.53 * * *$ & $-0.05 * * *$ & $-0.05 * * *$ & $-0.05 * * *$ & $-0.05 * * *$ & 1.00 & & & & & \\
\hline E\% & 8 & 8,561 & 16.829 & 2.098 & $-0.03^{* *}$ & -0.01 & $-0.02^{*}$ & $-0.02^{*}$ & -0.02 & $-0.02 *$ & -0.00 & 1.00 & & & & \\
\hline $\mathrm{FL}$ & 9 & 8,561 & 26.400 & 11.415 & -0.01 & $-0.02 *$ & $0.06 * * *$ & $0.07 * * *$ & $0.07 * * *$ & $0.07 * * *$ & $-0.02 * *$ & 0.00 & 1.00 & & & \\
\hline RQ & 10 & 8,561 & 1.43 & 0.571 & $0.04 * * *$ & $0.03^{* * *}$ & $0.09 * * *$ & $0.09 * * *$ & $0.11^{* * * *}$ & $0.11^{* * * *}$ & $0.15^{*}$ & 0.05 & $0.88^{* * *}$ & 1.00 & & \\
\hline RL & 11 & 8,561 & 1.47 & 0.710 & $0.05 * * *$ & $0.03^{* * *}$ & $0.15^{* * * *}$ & $0.15^{* * * *}$ & $0.09 * * *$ & $0.12^{* * *}$ & $0.17^{*}$ & $0.07^{*}$ & $0.87^{* * * *}$ & $0.89^{* * * *}$ & 1.00 & \\
\hline $\mathrm{CC}$ & 12 & 8,561 & 1.53 & 0.622 & $0.03 * *$ & $0.02 * * *$ & $0.12 * * *$ & $0.13^{* * *}$ & $0.21 * * *$ & $0.17^{* * *}$ & 0.11 & $0.08^{*}$ & $0.90^{* * *}$ & $0.84^{* * * *}$ & $0.88 * * *$ & 1.00 \\
\hline
\end{tabular}

Note. $* * *, * *, *$ indicate $1 \%, 5 \%$ and $10 \%$ level of significance respectively.

\subsection{Model Specification}

We regress corporate financial performance on the tailor-made CSP measures on four pillars of performance lagged by one year, employing fixed effects regressions panel data as suggested by the Hausman test. A fixed effects model is typically used when the observed quantities, in terms of explanatory variables, are treated as non-random. The equations used are:

$$
\begin{array}{r}
\mathrm{ROA}_{\mathrm{i}, \mathrm{t}}=\beta_{0}+\beta_{1} \mathrm{ECO}_{\mathrm{i}, \mathrm{t}-1}+\beta_{2} \mathrm{ENV}_{\mathrm{i}, \mathrm{t}-1}+\beta_{3} \mathrm{SOC}_{\mathrm{i}, \mathrm{t}-1}+\beta_{4} \mathrm{GOV}_{\mathrm{i}, \mathrm{t}-1}+\beta_{5} \mathrm{FS}_{\mathrm{i}, \mathrm{t}-1}+\beta_{6} \mathrm{E} \%_{\mathrm{i}, \mathrm{t}-1}+\beta_{7} \mathrm{FL}_{\mathrm{i}, \mathrm{t}-1}+ \\
\beta_{8} \mathrm{RQ}_{\mathrm{i}, \mathrm{t}}+\beta_{9} \mathrm{RL}_{\mathrm{i}, \mathrm{t}-1}+\beta_{10} \mathrm{CC}_{\mathrm{i}, \mathrm{t}-1}+\epsilon_{\mathrm{i}, \mathrm{t}} \\
\mathrm{TQ}_{\mathrm{i}, \mathrm{t}}=\beta_{0}+\beta_{1} \mathrm{ECO}_{\mathrm{i}, \mathrm{t}-1}+\beta_{2} \mathrm{ENV}_{\mathrm{i}, \mathrm{t}-1}+\beta_{3} \mathrm{SOC}_{\mathrm{i}, \mathrm{t}-1}+\beta_{4} \mathrm{GOV}_{\mathrm{i}, \mathrm{t}-1}+\beta_{5} \mathrm{FS}_{\mathrm{i}, \mathrm{t}-1}+\beta_{6} \mathrm{E}_{\mathrm{i}, \mathrm{t}-1}+\beta_{7} \mathrm{FL}_{\mathrm{i}, \mathrm{t}-1}+ \\
\beta_{8} \mathrm{RQ}_{\mathrm{i}, \mathrm{t}}+\beta_{9} \mathrm{RL}_{\mathrm{i}, \mathrm{t}-1}+\beta_{10} \mathrm{CC}_{\mathrm{i}, \mathrm{t}-1}+\epsilon_{\mathrm{i}, \mathrm{t}}
\end{array}
$$

Following literature in the field we recognize a potential bias from endogeneity between variables. Results obtained using fixed effect panel data regression could be, as consequence, inconsistent (Cui et al., 2016). More 
in detail, a first source of endogeneity may be due to simultaneity that arises if CSP measures are also affected by accounting and financial performance; moreover, an additional source of endogeneity may be found in unobserved heterogeneity. If there are unobservable factors specific to firms and industries that affect both financial performance and CSP: estimators, which, at this point, ignore this unobserved heterogeneity, result inconsistent (Wintoki et al., 2012). In addition, if ROA and Tobin's Q are dynamic, fixed effect estimators may be biased (Wooldridge, 2010). Due to these reasons, we apply a Dynamic Panel GMM estimation approach (Arellano \& Bover, 1995). The equations used to perform the GMM analysis are reported:

$$
\begin{array}{r}
\mathrm{ROA}_{\mathrm{i}, \mathrm{t}}=\beta_{0}+\beta_{1} \mathrm{ROA}_{\mathrm{i}, \mathrm{t}-1}+\beta_{2} \mathrm{ROA}_{\mathrm{i}, \mathrm{t}-2}+\beta_{3} \mathrm{ECO}_{\mathrm{i}, \mathrm{t}-1}+\beta_{4} \mathrm{ENV}_{\mathrm{i}, \mathrm{t}-1}+\beta_{5} \mathrm{SOC}_{\mathrm{i}, \mathrm{t}-1}+\beta_{6} \mathrm{GOV}_{\mathrm{i}, \mathrm{t}-1}+\beta_{7} \mathrm{FS}_{\mathrm{i}, \mathrm{t}-1}+ \\
\beta_{8} \mathrm{E} \%_{\mathrm{i}, \mathrm{t}-1}+\beta_{9} \mathrm{FL}_{\mathrm{i}, \mathrm{t}-1}+\beta_{10} \mathrm{RQ}_{\mathrm{i}, \mathrm{t}}+\beta_{11} \mathrm{RL}_{\mathrm{i}, \mathrm{t}-1}+\beta_{12} \mathrm{CC}_{\mathrm{i}, \mathrm{t}-1}+\epsilon_{\mathrm{i}, \mathrm{t}} \\
\mathrm{TQ}_{\mathrm{i}, \mathrm{t}}=\beta_{0}+\beta_{1} \mathrm{TQ}_{\mathrm{i}, \mathrm{t}-1}+\beta_{2} \mathrm{TQ}_{\mathrm{i}, \mathrm{t}-2}+\beta_{3} \mathrm{ECO}_{\mathrm{i}, \mathrm{t}-1}+\beta_{4} \mathrm{ENV}_{\mathrm{i}, \mathrm{t}-1}+\beta_{5} \mathrm{SOC}_{\mathrm{i}, \mathrm{t}-1}+\beta_{6} \mathrm{GOV}_{\mathrm{i}, \mathrm{t}-1}+\beta_{7} \mathrm{FS}_{\mathrm{i}, \mathrm{t}-1}+ \\
\beta_{8} \mathrm{E}_{\mathrm{i}, \mathrm{t}-1}+\beta_{9} \mathrm{FL}_{\mathrm{i}, \mathrm{t}-1}+\beta_{10} \mathrm{RQ}_{\mathrm{i}, \mathrm{t}}+\beta_{11} \mathrm{RL}_{\mathrm{i}, \mathrm{t}-1}+\beta_{12} \mathrm{CC}_{\mathrm{i}, \mathrm{t}-1}+\epsilon_{\mathrm{i}, \mathrm{t}}
\end{array}
$$

In order to test the effect that sector and geographical specificities have on the relationship between CSP and $\mathrm{CFP}$, we run further econometric analyses splitting the original sample on the basis of sector and geographic area and compare new results.

\section{Findings}

In this section we present and discuss model outcomes. With respect to the fixed effect estimators, economic and governance score, measuring the respective corporate performance, appear to positively affect both ROA and Tobin's Q (model 1 and 2 in Table 6), supporting hypotheses H1a, H1c, H2a and H2c. Instead, environmental and social scores negatively influence both accounting and financial performance, providing no support for

\begin{tabular}{|c|c|c|c|c|}
\hline & $\begin{array}{c}\text { Model } 1 \\
\text { ROA }\end{array}$ & $\begin{array}{c}\text { Model } 2 \\
\text { Tobin's Q }\end{array}$ & $\begin{array}{c}\text { Model } 3 \\
\text { ROA }\end{array}$ & $\begin{array}{c}\text { Model } 4 \\
\text { Tobin's Q }\end{array}$ \\
\hline \multirow{2}{*}{$\mathrm{ROA}_{\mathrm{t}-1}$} & & & $0.501 * * *$ & \\
\hline & & & $(0.124)$ & \\
\hline \multirow{2}{*}{$\mathrm{ROA}_{\mathrm{t}-2}$} & & & 0.0155 & \\
\hline & & & $(0.020)$ & \\
\hline \multirow{2}{*}{$\mathrm{TQ}_{\mathrm{t}-1}$} & & & & $0.583 * * *$ \\
\hline & & & & (0.137) \\
\hline \multirow{2}{*}{$\mathrm{TQ}_{\mathrm{t}-2}$} & & & & 0.011 \\
\hline & & & & $(0.024)$ \\
\hline \multirow{2}{*}{$\mathrm{ECO}$} & $0.174 * * *$ & $0.075^{* * *}$ & $0.330 * * *$ & $0.163 * * *$ \\
\hline & (0.043) & $(0.022)$ & $(0.057)$ & $(0.032)$ \\
\hline \multirow{2}{*}{ ENV } & $-0.354 * * *$ & $-0.127 * * *$ & $0.679 * * *$ & $0.271 * * *$ \\
\hline & (0.035) & (0.018) & $(0.074)$ & (0.035) \\
\hline \multirow{2}{*}{ GOV } & $0.536^{* * *}$ & $0.209 * * *$ & $0.955 * * *$ & $0.410 * * *$ \\
\hline & $(0.034)$ & $(0.017)$ & $(0.106)$ & $(0.056)$ \\
\hline \multirow{2}{*}{ SOC } & $-0.289 * * *$ & $-0.138 * * *$ & $0.461 * * *$ & $0.254 * * *$ \\
\hline & $(0.081)$ & $(0.041)$ & $(0.086)$ & (0.054) \\
\hline \multirow{2}{*}{ FS } & $0.424 * * *$ & $0.531 * * *$ & -0.314 & -0.173 \\
\hline & (0.104) & (0.053) & (0.713) & (1.613) \\
\hline \multirow{2}{*}{ FL } & $-2.238 * * *$ & $-1.173^{* * *}$ & $-4.238^{*}$ & -1.363 \\
\hline & (0.088) & $(0.024)$ & (3.254) & $(0.981)$ \\
\hline \multirow{2}{*}{$\mathrm{E} \%$} & $0.002 * *$ & $0.005^{* *}$ & 0.06 & 0.02 \\
\hline & $(0.009)$ & $(0.002)$ & $(0.040)$ & $(0.020)$ \\
\hline \multirow{2}{*}{ RQ } & $0.017^{*}$ & $0.017 * *$ & 0.017 & 0.017 \\
\hline & (0.008) & $(0.006)$ & $(0.010)$ & (0.013) \\
\hline \multirow{2}{*}{ RL } & 0.027 & $0.027 *$ & 0.027 & 0.027 \\
\hline & $(0.019)$ & (0.008) & $(0.011)$ & $(0.010)$ \\
\hline \multirow{2}{*}{$\mathrm{CC}$} & $0.021^{*}$ & $0.021^{*}$ & 0.021 & 0.021 \\
\hline & (0.009) & $(0.008)$ & $(0.011)$ & $(0.010)$ \\
\hline
\end{tabular}
hypotheses H1b, H1d, H2b and H2d. As previously explained, these results may be biased by endogeneity, and to this purpose, we run a dynamic system GMM analysis. Results are presented in Table 6 (model 3 and 4 ).

Table 6. Model outcome 


\begin{tabular}{lcccc}
\hline Year dummies & Yes & Yes & Yes & Yes \\
Fixed effects & Yes & Yes & & 3,962 \\
$\mathrm{~N}$ & 8,561 & 8,561 & 3,962 & \\
Adjusted $\mathrm{R}^{2}$ & 0.2337 & 0.093 & & $(0.001)$ \\
$\mathrm{AR}(1)$ test $(\mathrm{p}$ value) & & & $(0.174)$ & $(0.372)$ \\
$\mathrm{AR}(2)$ test $(\mathrm{p}$ value) & & & $(0.751)$ & $(0.451)$ \\
Hansen test over-identification & & & & \\
(p value) & & & & \\
\hline
\end{tabular}

This table displays fixed effect (model 1 and 2) and dynamic panel system GMM (model 3 and 4) regressions for the sample over the period of 2011-2017. The AR(1) and AR(2) tests are tests for first-order and second-order serial correlation in the first-differenced residuals, under the null of no serial correlation, respectively. The Hansen test of over-identifying restrictions is a test with the joint null hypothesis that instrumental variables are valid, i.e., uncorrelated with error terms. $* * * * *$, and * indicate statistical significance at the 1,5, and $10 \%$ levels, respectively.

Our GMM approach offers evidence of a positive relationship between CSP and financial performance. Dependent variables (ROA and Tobin's Q) appear to be significantly influenced by all pillars of CSP, offering support for all our hypotheses. To further corroborate the robustness of our analysis, we run an autocorrelation test in order ensure our dependent variables are dynamic, an essential condition to implement the GMM approach. The $\mathrm{AR}(1)$ and $\mathrm{AR}(2)$ tests for first- and second-order serial correlation in the first-differenced residuals suggest that, under the null hypothesis of no serial correlation, $A R(1)$ is serially correlated but $A R(2)$ is uncorrelated. What is more, our instrumental variables result valid (Hansen test) given lack of correlation with the error terms (Arellano \& Bond, 1990).

In order to better understand the impact of CSP aspects on corporate financial performance, Tables 7 and 8 present findings when the base model is run on the sample divided by sector and geographical area. As is possible to note in Table 7 , there is a positive and statistically significant relationship between ROA and all aspects of CSP considered in the following sectors: Industrials, Basic Materials, Oil \& Gas and Utilities. In the Financial sector, on the other hand, we find a positive relationship between ROA and environmental, governance and social scores. The relationship is weaker in Consumer Goods, Consumer Services, Healthcare and Technology, while there is no significant relationship in the Telecommunications sector.

With regard to the relationship between Tobin's Q and CSP pillars, Basic Materials, Technology, Oil \& Gas and Utilities are the sectors in which the relationship results stronger, followed by Industrials and Financials. At the same time, we find no significant relationship between CSP and CFP in Consumer Goods, Consumer Services, Healthcare and Telecommunications. A possible explanation may lie in the fact that in Industrials, Basic Materials, Oil \& Gas and Utilities sectors stakeholders exercise more intense pressures, obliging firms to invest in ESG initiatives, given the increased associated externalities linked to negative market reactions (Blasi et al., 2018). Concerning the Financials sector, finally, the relationship between CSP and financial performance is surprisingly positive and statistically significant, probably due to the growing importance that sustainability is assuming in the sector (Garbarino \& Johnson, 1999; Kolk, 2003; Scholtens, 2006; Maturte-Vallejo et al., 2011). Financial institutions and banks in particular "are improving their corporate image, brand loyalty, and consumer perception in terms of CSR because of lowered consumer empathy towards the sector" (Salvi et al., 2018).

Table 8 presents findings by geographical area. In particular, the effect of CSP on CFP is stronger in North America and Europe with respect to Asia and South America. Findings confirm the idea that "the geopolitical atmosphere in Europe may be more conducive to focusing on social and environmental concerns" (Tschopp, 2005).

Table 7. Sectorial regression analysis

\begin{tabular}{|c|c|c|c|c|c|c|c|c|c|c|c|c|c|c|c|c|c|c|c|c|c|c|c|c|c|c|c|c|c|c|c|c|c|c|c|}
\hline & \multicolumn{4}{|c|}{ Financial } & \multicolumn{3}{|c|}{ Industrial } & \multicolumn{4}{|c|}{$\begin{array}{c}\text { Consumer } \\
\text { Goods }\end{array}$} & \multicolumn{3}{|c|}{\begin{tabular}{|c|}
$\begin{array}{c}\text { Consumer } \\
\text { Services }\end{array}$ \\
\end{tabular}} & \multicolumn{4}{|c|}{ Healthcare } & \multicolumn{4}{|c|}{ Basic Meterials } & \multicolumn{3}{|c|}{ Technology } & \multicolumn{4}{|c|}{ Oil \& Gas } & \multicolumn{3}{|c|}{ Utilities } & \multicolumn{3}{|c|}{ Telecom. } \\
\hline & 榙 & 罗 & ¿̨) & & 娄 & $\frac{\pi}{2}$ & 咢 & 荇 & 罗 & $\stackrel{8}{8}$ & ஜ̆ & \begin{tabular}{l|}
$\pi$ \\
\end{tabular} & 罗主 & : & 范 & 罗 & 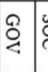 & 气̊ & రั & & $\check{g}$ & & 范 & 8 & 8 & 图 & $\frac{\pi}{4}$ & @ి & $\check{\swarrow}$ & 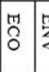 & 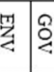 & $\check{2}$ & 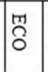 & & 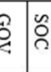 \\
\hline $\begin{array}{l}R \\
O \\
A\end{array}$ & & + & + & + & + & + & + & & & + & & & + & & + & & & & + & + & + & + & 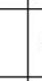 & + & & + & + & + & + & + & + & + & & & \\
\hline $\begin{array}{l}T \\
Q \\
Q\end{array}$ & & + & + & & + & & . & & & & & & & & & & & & + & + & + & + & + & + & + & + & + & + & + & + & + & + & & & \\
\hline
\end{tabular}


This table displays the impact of ESG scores on dependent variables in each sector. + indicates a positive significant relationship at least $10 \%$, - indicates a negative significant relationship at least $10 \%$. Empty cell indicates that the estimator is not statistically significant.

Table 8. Geographical regression analysis

\begin{tabular}{|c|c|c|c|c|c|c|c|c|c|c|c|c|c|c|c|c|}
\hline & \multicolumn{4}{|c|}{ North America } & \multicolumn{4}{|c|}{ Europe } & \multicolumn{4}{|c|}{ Asia } & \multicolumn{4}{|c|}{ South America and Oceania } \\
\hline & $\stackrel{T}{0}$ & $\underset{Z}{\mathbb{Z}}$ & $\stackrel{Q}{Q}$ & $\mathscr{\wp}$ & $\stackrel{T}{0}$ & $\underset{Z}{\mathbb{Z}}$ & $\stackrel{\Omega}{0}$ & ஜூ & $\stackrel{\Gamma}{\Omega}$ & $\underset{殳}{\mathbb{Z}}$ & 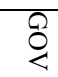 & $\stackrel{\mathscr{\Omega}}{\varrho}$ & $\stackrel{T}{0}$ & $\underset{\mathrm{Z}}{\mathrm{N}}$ & $\stackrel{Q}{0}$ & $\stackrel{\mathscr{D}}{\varrho}$ \\
\hline ROA & + & + & + & + & + & + & + & + & & + & + & & & + & + & \\
\hline TQ & & + & + & & + & + & + & + & & + & + & & & + & + & \\
\hline
\end{tabular}

This table displays the impact of ESG scores on dependent variables in each sector. + indicates a positive significant relationship at least $10 \%$, - indicates a negative significant relationship at least $10 \%$. Empty cell indicates that the estimator is not statistically significant.

\section{Conclusions}

This study analyses the relationship between CSP and CFP making an attempt to account for controversial results obtained by researchers during the past decades (Margolis \& Walsh, 2003; Endrikat, 2016).

One key contribution of this work lies in its operationalization of CSP that allows accounting for sector and country specificities, due to their importance in planning and implementing CSR strategies, as postulated by Mallin et al. (2014) and Blasi et al. (2018). In order to do this, we recalculate the ESG performance pillars provided by Asset4 using a z-score approach as explained in the "Methodology" section.

Our second key contribution is found in the implementation of a GMM approach to mitigate endogeneity bias coming from reverse causality and omitted variable biases potentially affecting our dataset. Findings obtained using the GMM approach are consistent with literature in the field, further corroborating a positive relationship between CSP dimensions (economic, environmental, governance and social) and corporate financial performance, in terms of both accounting and market-based measures. In addition, findings highlight sector specificities as a determining factor shaping the relationship of interest. Firms operating in the Industrials, Basic Materials, Oil \& Gas and Utilities sectors, particularly proactive in terms of ESG initiatives, reap higher financial benefits with respect to less sustainable counterparts of the same sector. The economic rationale is based on the increased environmental costs associated with the aforementioned sectors determining stronger stakeholder pressures (Blasi et al., 2018). In the Financial sector, although to a lesser extent, the relationship between CSP and CFP results relevant due to the growing importance sustainability is assuming in reinforcing relationships with stakeholders and a good citizen agenda (Matute-Vallejo et al., 2011).

At this point, we could not fail to recognize this study's limitations giving space to potential for new research. More specifically, new studies may analyse the relationship between CSP and CFP delving deeper into the non-linear relationship between the variables considered. Moreover, it could be interesting to employ further operationalization schemes that would expand findings and their implications. A particular focus on the difference between developed and non-developed countries may also generate valuable new knowledge with respect to the differences sustainability presents in terms of perception, implementation and value generation.

\section{References}

Alafi, K., \& Hasoneh, A. B. (2012). Corporate social responsibility associated with customer satisfaction and financial performance a case study with Housing Banks in Jordan. International Journal of Humanities and Social Science, 2(15),

102-115. http://www.ijhssnet.com/view.php?u=https://www.ijhssnet.com/journals/Vol_2_No_15_August_2012/13.p df

Alexander, G. J., \& Buchholz, R. A. (1978). Corporate social responsibility and stock market performance. Academy of Management Journal, 21(3), 479-486. https://doi.org/10.5465/255728

Al-Tuwaijri, S. A., Christensen, T. E., \& Hughes Ii, K. E. (2004). The relations among environmental disclosure, environmental performance, and economic performance: A simultaneous equations approach. Accounting, Organizations and Society, 29(5-6), 447-471. https://doi.org/10.1016/S0361-3682(03)00032-1 
Arellano, M., \& Bover, O. (1995). Another look at the instrumental variable estimation of error-components models. Journal of Econometrics, 68(1), 29-51. https://doi.org/10.1016/0304-4076(94)01642-D

Attig, N., El Ghoul, S., Guedhami, O., \& Suh, J. (2013). Corporate social responsibility and credit ratings. Journal of Business Ethics, 117(4), 679-694. https://doi.org/10.1007/s10551-013

Aupperle, K. E., Carroll, A. B., \& Hatfield, J. D. (1985). An empirical examination of the relationship between corporate social responsibility and profitability. Academy of Management Journal, 28(2), 446-463. https://doi.org/10.5465/256210

Bansal, P. (2005). Evolving sustainably: A longitudinal study of corporate sustainable development. Strategic Management Journal, 26(3), 197-218. https://doi.org/10.1002/smj.441

Barnett, M. L. (2007). Stakeholder influence capacity and the variability of financial returns to corporate social responsibility. Academy of Management Review, 32(3), 794-816. https://doi.org/10.5465/amr.2007.25275520.

Barney, J. (1991). Firm resources and sustained competitive advantage. Journal of Management, 17(1), 99-120. https://doi.org/10.1177/014920639101700108

Blasi, S., Caporin, M., \& Fontini, F. (2018). A multidimensional analysis of the relationship between corporate social responsibility and firms' economic performance. Ecological Economics, 147, 218-229. https://doi.org/10.1016/j.ecolecon.2018.01.014

Bragdon, J. H., \& Marlin, J. (1972). Is pollution profitable. Risk Management, 19(4), 9-18. https://doi.org/10.1016/j.ecolecon.2018.01.014

Brammer, S., Brooks, C., \& Pavelin, S. (2006). Corporate social performance and stock returns: UK evidence from disaggregate measures. Financial Management, https://doi.org/10.1111/j.1755-053X.2006.tb00149.X

Briloff, A. J. (1981). The truth about corporate accounting. Harpercollins.

Campbell, J. L. (2007). Why would corporations behave in socially responsible ways? An institutional theory of corporate social responsibility. Academy of Management Review, 32(3), 946-967. https://doi.org/10.5465/amr.2007.25275684

Chen, H., \& Wang, X. (2011). Corporate social responsibility and corporate financial performance in China: an empirical research from Chinese firms. Corporate Governance: The International Journal of Business in Society, 11(4), 361-370. https://doi.org/10.1108/14720701111159217

Cho, S. J., Chung, C. Y., \& Young, J. (2019). Study on the Relationship between CSR and Financial Performance. Sustainability, 11(2), 343. https://doi.org/10.3390/su11020343

Chollet, P., \& Sandwidi, B. W. (2018). CSR engagement and financial risk: A virtuous circle? International evidence. Global Finance Journal, 38, 65-81. https://doi.org/10.1016/j.gfj.2018.03.004

Clark, G. L., \& Viehs, M. (2014). The implications of corporate social responsibility for investors: An overview and evaluation of the existing CSR literature. Available at SSRN 2481877

Cui, J., Jo, H., \& Na, H. (2018). Does corporate social responsibility affect information asymmetry? Journal of Business Ethics, 148(3), 549-572. https://doi.org/10.1007/s10551-015-3003-8

Dowell, G., Hart, S., \& Yeung, B. (2000). Do corporate global environmental standards create or destroy market value? Management Science, 46(8), 1059-1074. https://doi.org/10.1287/mnsc.46.8.1059.12030

Dyduch, J., \& Krasodomska, J. (2017). Determinants of corporate social responsibility disclosure: An empirical study of Polish listed companies. Sustainability, 9(11), 1934. https://doi.org/10.3390/su9111934

El Ghoul, S., Guedhami, O., Kwok, C. C., \& Mishra, D. R. (2011). Does corporate social responsibility affect the cost of capital? Journal of Banking \& Finance, 35(9), 2388-2406. https://doi.org/10.1016/j.jbankfin.2011.02.007

Ellis, L., \& Bastin, C. (2011). Corporate social responsibility in times of recession: changing discourses and implications for policy and practice. Corporate Social Responsibility and Environmental Management, 18(5), 294-305. https://doi.org/10.1002/csr.254

Endrikat, J. (2016). Market reactions to corporate environmental performance related events: A meta-analytic consolidation of the empirical evidence. Journal of Business Ethics, 138(3), 535-548. https://doi.org/10.1007/s10551-015-2598-0 
Esteban-Sanchez, P., de la Cuesta-Gonzalez, M., \& Paredes-Gazquez, J. D. (2017). Corporate social performance and its relation with corporate financial performance: International evidence in the banking industry. Journal of Cleaner Production, 162, 1102-1110. https://doi.org/10.1016/j.jclepro.2017.06.127

Fatemi, A., Fooladi, I., \& Tehranian, H. (2015). Valuation effects of corporate social responsibility. Journal of Banking \& Finance, 59, 182-192. https://doi.org/10.1016/j.jbankfin.2015.04.028

Fatemi, A., Glaum, M., \& Kaiser, S. (2017). ESG performance and firm value: The moderating role of disclosure. Global Finance Journal, 38, 45-64. https://doi.org/10.1016/j.gfj.2017.03.001

Fijałkowska, J., Zyznarska-Dworczak, B., \& Garsztka, P. (2018). Corporate social-environmental performance versus financial performance of banks in Central and Eastern European countries. Sustainability, 10(3), 772. https://doi.org/10.3390/su10030772

Freeman, R. E. (1984). Strategic Management. A stakeholder Approach. Pitman/Ballinger (Harper Collins): Boston.

Friedman, M. (1970), reprinted from (1962). The social responsibility of business is to increase its profits. New York Times Magazine.

Galbreath, J., \& Shum, P. (2012). Do customer satisfaction and reputation mediate the CSR-FP link? Evidence from Australia. Australian Journal of Management, 37(2), 211-229. https://doi.org/10.1177/0312896211432941

Gangi, F., Meles, A., Monferrà, S., \& Mustilli, M. (2018). Does corporate social responsibility help the survivorship of SMEs and large firms? Global Finance Journal. https://doi.org/10.1016/j.gfj.2018.01.006

Garbarino, E., \& Johnson, M. S. (1999). The different roles of satisfaction, trust, and commitment in customer relationships. Journal of Marketing, 63(2), 70-87. https://doi.org/10.1177/002224299906300205

Godfrey, P. C., Merrill, C. B., \& Hansen, J. M. (2009). The relationship between corporate social responsibility and shareholder value: An empirical test of the risk management hypothesis. Strategic Management Journal, 30(4), 425-445. https://doi.org/10.1002/smj.750

Griffin, J. J., \& Mahon, J. F. (1997). The corporate social performance and corporate financial performance debate: Twenty-five years of incomparable research. Business \& Society, 36(1), 5-31. https://doi.org/10.1177/000765039703600102

Hamilton, J. T. (1995). Pollution as news: Media and stock market reactions to the toxics release inventory data. Journal of Environmental Economics and Management, 28(1), 98-113. https://doi.org/10.1006/jeem.1995.1007

Hart, S. L., \& Ahuja, G. (1996). Does it pay to be green? An empirical examination of the relationship between emission reduction and firm performance. Business Strategy and the Environment, 5(1), 30-37. https://doi.org/10.1002/(SICI)1099-0836(199603)5:1<30::AID-BSE38>3.0.CO;2-Q

Hassel, L., Nilsson, H., \& Nyquist, S. (2005). The value relevance of environmental performance. European Accounting Review, 14(1), 41-61. https://doi.org/10.1080/0963818042000279722

Horváthová, E. (2010). Does environmental performance affect financial performance? A meta-analysis. Ecological Economics, 70(1), 52-59. https://doi.org/10.1016/j.ecolecon.2010.04.004

Ioannou, I., \& Serafeim, G. (2015). The impact of corporate social responsibility on investment recommendations: Analysts' perceptions and shifting institutional logics. Strategic Management Journal, 36(7), 1053-1081. https://doi.org/10.1002/smj.2268

Jaggi, B., \& Freedman, M. (1992). An examination of the impact of pollution performance on economic and market performance: pulp and paper firms. Journal of Business Finance \& Accounting, 19(5), 697-713. https://doi.org/10.1111/j.1468-5957.1992.tb00652.x

Jo, H., \& Harjoto, M. A. (2011). Corporate governance and firm value: The impact of corporate social responsibility. Journal of Business Ethics, 103(3), 351-383. https://doi.org/10.1007/s10551-011-0869-y

Kaufmann, D., Kraay, A., \& Mastruzzi, M. (2009). Governance matters VIII: Aggregate and individual governance indicators 1996-2008. The World Bank.

King, A. A., \& Lenox, M. J. (2001). Does it really pay to be green? An empirical study of firm environmental and financial performance: An empirical study of firm environmental and financial performance. Journal of Industrial Ecology, 5(1), 105-116. https://doi.org/10.1162/108819801753358526 
Klassen, R. D., \& McLaughlin, C. P. (1996). The impact of environmental management on firm performance. Management Science, 42(8), 1199-1214. https://doi.org/10.1287/mnsc.42.8.1199

Kolk, A. (2003). Trends in sustainability reporting by the Fortune Global 250. Business strategy and the Environment, 12(5), 279-291. https://doi.org/10.1002/bse.370

Lin, C. H., Yang, H. L., \& Liou, D. Y. (2009). The impact of corporate social responsibility on financial performance: Evidence from business in Taiwan. Technology in Society, 31(1), 56-63. https://doi.org/10.1016/j.techsoc.2008.10.004

Lioui, A., \& Sharma, Z. (2012). Environmental corporate social responsibility and financial performance: Disentangling direct and indirect effects. Ecological Economics, 78, 100-111. https://doi.org/10.1016/j.ecolecon.2012.04.004

Lorraine, N. H. J., Collison, D. J., \& Power, D. M. (2004). An analysis of the stock market impact of environmental performance information. In Accounting Forum (Vol. 28, No. 1, pp. 7-26). Taylor \& Francis.

Mallin, C., Farag, H., \& Ow-Yong, K. (2014). Corporate social responsibility and financial performance in Islamic banks. Journal of Economic Behavior \& Organization, 103, S21-S38. https://doi.org/10.1016/j.jebo.2014.03.001

Manrique, S., \& Martí-Ballester, C. P. (2017). Analyzing the effect of corporate environmental performance on corporate financial performance in developed and developing countries. Sustainability, 9(11), 1957. https://doi.org/10.3390/su9111957

Margolis, J. D., \& Walsh, J. P. (2003). Misery loves companies: Rethinking social initiatives by business. Administrative Science Quarterly, 48(2), 268-305. https://doi.org/10.2307/3556659

Margolis, J. D., Elfenbein, H. A., \& Walsh, J. P. (2007). Does it pay to be good? A meta-analysis and redirection of research on the relationship between corporate social and financial performance. Ann Arbor, 1001, 48109-1234.

Matute-Vallejo, J., Bravo, R., \& Pina, J. M. (2011). The influence of corporate social responsibility and price fairness on customer behaviour: evidence from the financial sector. Corporate Social Responsibility and Environmental Management, 18(6), 317-331. https://doi.org/10.1002/csr.247

McGuire, J. B., Sundgren, A., \& Schneeweis, T. (1988). Corporate social responsibility and firm financial performance. Academy of Management Journal, 31(4), 854-872. https://doi.org/10.5465/256342

McWilliams, A., \& Siegel, D. (2001). Corporate social responsibility: A theory of the firm perspective. Academy of management review, 26(1), 117-127. https://doi.org/10.5465/amr.2001.4011987

Nelling, E., \& Webb, E. (2009). Corporate social responsibility and financial performance: the "virtuous circle" revisited. Review of Quantitative Finance and Accounting, 32(2), 197-209. https://doi.org/10.1007/s11156-008-0090-y

Orlitzky, M., Schmidt, F. L., \& Rynes, S. L. (2003). Corporate social and financial performance: A meta-analysis. Organization Studies, 24(3), 403-441. https://doi.org/10.1177/0170840603024003910

Preston, L. E., \& O'Bannon, D. P. (1997). The corporate social-financial performance relationship: A typology and analysis. Business \& Society, 36(4), 419-429. https://doi.org/10.1177/000765039703600406

Renneboog, L., Ter Horst, J., \& Zhang, C. (2008). Socially responsible investments: Institutional aspects, performance, and investor behavior. Journal of Banking \& Finance, 32(9), 1723-1742. https://doi.org/10.1016/j.jbankfin.2007.12.039

Rettab, B., Brik, A. B., \& Mellahi, K. (2009). A study of management perceptions of the impact of corporate social responsibility on organisational performance in emerging economies: the case of Dubai. Journal of Business Ethics, 89(3), 371-390. https://doi.org/10.1007/s10551-008-0005-9

Russo, M. V., \& Fouts, P. A. (1997). A resource-based perspective on corporate environmental performance and profitability. Academy of Management Journal, 40(3), 534-559. https://doi.org/10.5465/257052

Salvi, A., Petruzzella, F., \& Giakoumelou, A. (2018). CSR and Financial Performance: Trick or Treat? A Longitudinal Study on Holistic CSR Practices. International Journal of Business and Management, 13(6), 43-71. doi:10.5539/ijbm.v13n6p43

Scholtens, B. (2006). Finance as a driver of corporate social responsibility. Journal of Business Ethics, 68(1), 19-33. https://doi.org/10.1007/s10551-006-9037-1 
Semenova, N., \& Hassel, L. G. (2015). On the validity of environmental performance metrics. Journal of Business Ethics, 132(2), 249-258. https://doi.org/10.1007/s10551-014-2323-4

Shane, P. B., \& Spicer, B. H. (1983). Market response to environmental information produced outside the firm. The Accounting Review, 58(3), 521. https://search.proquest.com/openview/95680272d2723f7ccb5a3a36d4a2716a/1?pq-origsite=gscholar\&cbl= 1816369

Soana, M. G. (2011). The relationship between corporate social performance and corporate financial performance in the banking sector. Journal of Business Ethics, 104(1), 133. https://doi.org/10.1007/s10551-011-0894-x.

Stanwick, P. A., \& Stanwick, S. D. (1998). The relationship between corporate social performance, and organizational size, financial performance, and environmental performance: An empirical examination. Journal of Business Ethics, 17(2), 195-204. https://doi.org/10.1023/A:1005784421547

Tschopp, D. J. (2005). Corporate social responsibility: a comparison between the United States and the European Union. Corporate Social Responsibility and Environmental Management, 12(1), 55-59. https://doi.org/10.1002/csr.69

Vance, S. C. (1975). Are socially responsible corporations good investment risks? Management Review, 64(8), 19-24.

Vastola, V., Russo, A., \& Vurro, C. (2017). Dealing with cultural differences in environmental management: Exploring the CEP-CFP relationship. Ecological Economics, 134, 267-275. https://doi.org/10.1016/j.ecolecon.2016.11.006

Waddock, S. A., \& Graves, S. B. (1997). The corporate social performance-financial performance link. Strategic $\begin{array}{llll}\text { Management } & \text { Journal, } & \text { 303-319. }\end{array}$ https://doi.org/10.1002/(SICI)1097-0266(199704)18:4<303::AID-SMJ869>3.0.CO;2-G

Wagner, M. (2005). How to reconcile environmental and economic performance to improve corporate sustainability: corporate environmental strategies in the European paper industry. Journal of Environmental Management, 76(2), 105-118. https://doi.org/10.1016/j.jenvman.2004.11.021

Wang, Q., Dou, J., \& Jia, S. (2016). A meta-analytic review of corporate social responsibility and corporate financial performance: The moderating effect of contextual factors. Business \& Society, 55(8), 1083-1121. https://doi.org/10.1177/0007650315584317

Wintoki, M. B., Linck, J. S., \& Netter, J. M. (2012). Endogeneity and the dynamics of internal corporate governance. Journal of Financial Economics, 105(3), 581-606. https://doi.org/10.1016/j.jfineco.2012.03.005

Wood, D. J., \& Jones, R. E. (1995). Stakeholder mismatching: A theoretical problem in empirical research on corporate social performance. The International Journal of Organizational Analysis, 3(3), 229-267. https://doi.org/10.1108/eb028831

Wooldridge, J. M. (2010). Econometric analysis of cross section and panel data. MIT press.

Yang, S. L. (2016). Corporate social responsibility and an enterprise's operational efficiency: considering competitor's strategies and the perspectives of long-term engagement. Quality \& Quantity, 50(6), 2553-2569. https://doi.org/10.1007/s11135-015-0276-z

\section{Notes}

Note 1 . The S\&P Global 1200 provides efficient exposure to the global equity market. Capturing approximately $70 \%$ of global market capitalization, it is constructed as a composite of 7 headline indices, many of which are accepted leaders in their regions. These include the S\&P 500® (US), S\&P Europe 350, S\&P TOPIX 150 (Japan), S\&P/TSX 60 (Canada), S\&P/ ASX All Australian 50, S\&P Asia 50 and S\&P Latin America 40.

Note 2. "The WGI cover over 200 countries and territories, measuring six dimensions of governance starting in 1996: Voice and Accountability, Political Stability and Absence of Violence/Terrorism, Government Effectiveness, Regulatory Quality, Rule of Law, and Control of Corruption” (Kaufmann et al., 2008).

Note 3. We consider four geographic areas: North America, Europe, Asia and South America and Oceania. 


\section{Copyrights}

Copyright for this article is retained by the author(s), with first publication rights granted to the journal.

This is an open-access article distributed under the terms and conditions of the Creative Commons Attribution license (http://creativecommons.org/licenses/by/4.0/). 